Revista de la red interuniversitaria de estudios sobre las literaturas rioplatenses contemporáneas en Francia

$18 \mid 2018$

El río y la ciudad

\title{
Está muy cerca. La ciudad lo ignora pero él la mira
}

\section{Graciela Villanueva}

\section{OpenEdition}

Journals

Edición electrónica

URL: http://journals.openedition.org/lirico/5801

DOI: 10.4000/lirico.5801

ISSN: 2262-8339

Editor

Réseau interuniversitaire d'étude des littératures contemporaines du Río de la Plata

Referencia electrónica

Graciela Villanueva, «Está muy cerca. La ciudad lo ignora pero él la mira », Cuadernos LIRICO [En línea], 18 | 2018, Puesto en línea el 14 octubre 2018, consultado el 03 mayo 2019. URL : http:// journals.openedition.org/lirico/5801; DOI : 10.4000/lirico.5801

Este documento fue generado automáticamente el 3 mayo 2019.

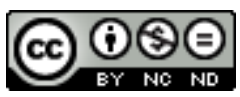

Cuadernos LIRICO está distribuido bajo una Licencia Creative Commons Atribución-NoComercialSinDerivar 4.0 Internacional. 


\title{
Está muy cerca. La ciudad lo ignora pero él la mira
}

\author{
Graciela Villanueva
}

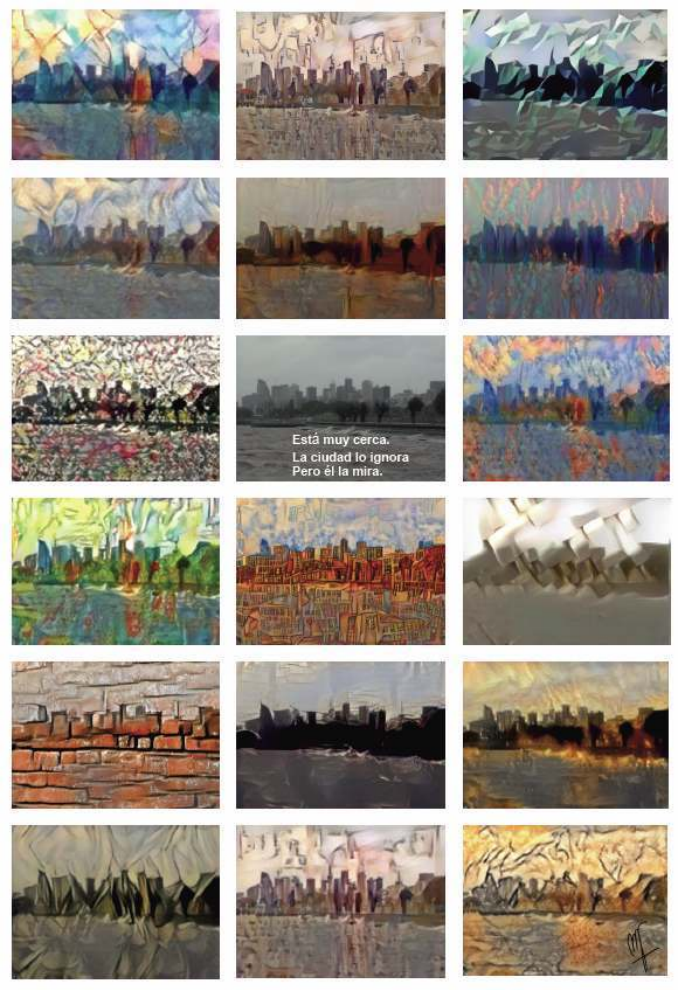

